\title{
EUROPEAN UNION LEGAL NATURE: EU AS SUI GENERIS - A PLATYPUS-LIKE SOCIETY
}

\author{
Katarina Peročević ${ }^{*}$
}

\begin{abstract}
The question of the legal nature of the European Union (hereafter: the EU) has been left unanswered to date. Determining the legal nature is important for predicting the consequences, limits and ways of action of any organization, including the EU. Today, the EU is most often defined as a sui generis organization. Given the limited analytical value of the term sui generis, it is important to determine its content. For this purpose, it is necessary to analyze, along with the political aspect of the community, the formal and legal ones, which includes the analysis of federal, international and other elements contained in the legal and political system of the EU.

Also, a comparison between the formal and political elements of the EU and a typical federal society such as the United States of America will be made, with the aim of determining the specific features of the EU which prevent it from being called "the United States of Europe". The most prominent definitions of the EU offered by prominent theorists will be briefly addressed in this article.
\end{abstract}

KEYWORDS: EU, sui generis, federation, international organization, US federal system, prominent theoreticians

\section{INTRODUCTION}

"E. Burke said that political orders do not occur on drawing boards, but they must be allowed to occur". ${ }^{1}$

The establishment of the European Community (hereafter: the EC) in the second half of the 20th century implied the necessity for determining the political and organizational elements of the system.

PhD Candidate at University of Zagreb, Faculty of Law; katarinaperocevic@gmail.com.

1 Posavec, Z.: A path towards a united Europe, Politička misao, vol. 28 (1) 1991, p. 6. 
At that time, discussions regarding legal nature were conducted both in Europe and in the United States of America (hereafter: the USA), and opinions varied. $^{2}$ The State Department concluded that the new united Europe should have a primarily economic role, while in Europe there were various ideas, from the Federalist, the Social democrats to the Unionists, the opponents of institutionalization. ${ }^{3}$

The European Union of today emerged on the foundations of the European Coal and Steel Community, perceived at that time as an international organization, with an increasing number of federal elements.

History shows that development from the EC, mainly an economic system, to the EU, an economic and political system, progressed rapidly. There are many factors that either provoked or influenced the changes of the legal nature of the EU. The following can be adduced as influential formal factors: the changes of EU Treaties, changes in the institutional organization of the system, changes in the decision-making process, alteration of types and effects of EU legislation, modifications of EU competences, enlargement of the community and so on.

Moreover, the following can be adduced as influential political factors: the creation of policy guidelines from institutions such as the European Court of Justice (hereafter: the ECJ) and the European Council, which the legal nature of the EU is largely modelled on. The question which remains unanswered is whether the formal factors affect the change of the legal nature of the EU or the abovementioned factors are changing due to influential political factors. The following analysis of the formal legal and political elements from the emergence of the European Community until today will be an attempt to answer that question, as well as the aforementioned one: What is the content of the term sui generis?

\footnotetext{
2 Vukadinović, R. et al., European integration policy, Zagreb, 2005, p. 52

3 The concept of federal Europe was advocated by Robert Schumann, Jean Monnet, Walter Hallstein, Konrad Adenauer, Alcide de Gasperi. They presented their ideas at the Hague Congress (1948) that was attended by around 700 delegates from 16 countries and was important for the issue of the character of the new community. Vukadinović, R. et al., European integration policy, Zagreb, 2005, p. 52.
} 


\section{LEGAL AND POLITICAL DETERMINANTS OF THE LEGAL NATURE OF THE EU}

\subsection{ESTABLISHMENT OBJECTIVES AND FOUNDING TREATIES}

"Force enemies to jointly build the castle and you'll turn them into brothers". ${ }^{4}$ States form organizations and alliances for a variety of reasons; however, history shows that the most common motive is defense, that is, the desire to defend oneself against an external enemy. Unlike in a typical confederation in which states create a new subject of international law for the purpose of self-defense, the EC was established with the aim of integration in the economic field. ${ }^{5}$

In the 1950s, the EC was considered to be a typical international organization or confederation, established by an international treaty which can be amended only with the approval of all Member States. At that time, the EC consisted of two separate communities, each with its own legal capacity and two areas of international cooperation. It was not authorized to enter into any agreements, including with third countries, which was the element that differentiated it from international organizations and confederations. ${ }^{6}$

In the 1990s, with the entry into force of the Treaty of Maastricht, the change of the Founding Treaties resulted in serious discussions of the EU as a federal state. European integration led from predominantly economic integration to political unity, and the sovereignty of Member States was a key issue for the organization of the EU legal system. The objectives of the economic and monetary union, the single currency, the common foreign and security policy, the common defense policy, and the close cooperation in the field of justice and home affairs were all regulated. The Treaty of Maastricht sought to unite the economic, monetary and political dimension of the EU. In response to the changes, the German Constitutional Court rendered the Maastricht Urteil judgment in which it raised the issue of control over decision-making in the EU. It concluded that the source of legitimacy in the EU decision-making process are the citizens, and the Member States are the ones who decide on the transfer and conferral of their competence to the EU.? It called the European

\footnotetext{
4 Mintas Hodak, Lj., European Union, Zagreb, 2010, p. 2.

5 Degan, Đ.: Confederalism, Politička misao, vol. 28 (2) 1991, pp. 7 - 8.

6 Under the Lisbon Treaty, the European Union has acquired legal personality and the international legal capacity to conclude contracts with third countries or international organizations. Consolidated version of the Treaty on the Functioning of the European Union, (OJ C 326, 26/10/2012) Art. 3; Art. 47.

7 Bonechi, G.: The Legal Nature of the European Union: a Federal Approach, Luiss Guido Carli - Libera Universita internazionale, 2015, p. 33.
} 
Union "Staatverbund", which means "the state alliance". In that sense, the EU would be a confederation. ${ }^{8}$

That judgement was aimed at confirming the non-federal character of the EU, considering that there is no intention of creating "the United States of Europe".

Under the Treaties of Amsterdam and Nice, the EU was focused on changes in the functioning of the institutions and the acceptance of new member states. These Treaties opened the way for the adoption of the European Constitution. The Convention on the Future of Europe has raised issues of importance regarding the legal nature of the EU, such as the way of applying the federal principle, the question of shared sovereignty, national identity, and autonomy of the Member States.

As a result of the debate, a Constitutional Treaty was adopted which did not come into force as it was rejected in referendums in the Netherlands and France in 2005. The Lisbon Reform Treaty, which entered into force in 2009, provided the EU with legal personality and international legality. Although not formally confirmed, these changes have led to the predominance of federal elements in the EU.

\subsection{THE DECISION-MAKING PROCESS}

For decades, EC decisions were made according to the intergovernmental principle, unanimously, on the principle of equality, as in international organizations. The establishment of the European Council brought about change by strengthening the position of the Council and by enacting a qualified majority vote, thus enabling the EC to assume a federal element. The EU decides unanimously on important issues such as changes in the organization, changes of the EU Treaty and the Treaty on the Functioning of the European Union, the budget and so on. Thus, there is a mixture of federal and confederal elements in the decision-making process.

\footnotetext{
8 Case 89 BVerfGE 155 [12/10/1993] Bundesverfassungsgericht.

9 Baletić, M.: Legal Characteristics of the process of creation and enlargement of the European Union, Međunarodne studije: časopis za međunarodne odnose, vanjsku politiku i diplomaciju, vol. 6 (2) 2006, p. 23.
} 


\subsection{ACTS AND THEIR LEGAL EFFECT IN THE EU}

In federal systems, acts are binding on member states, but this is also possible in countries that accept the monistic concept of international treaties. ${ }^{10}$ In international organizations acts have the force of recommendations and are not binding on member states. In a confederation, the citizens of member states shall not be bound by the decisions made by confederation bodies until they enter their legislation. Citizens do not have direct relations with confederal bodies but have direct relations with the bodies of member states, as is the case in the European Union. The EU issues binding legislation, except for recommendations and opinions. The EU has two instruments which have a direct impact on EU citizens. The first are Regulations which have a general and direct effect and are binding in their entirety. Decisions are the second instrument, and they are binding in their entirety. The Regulations and the Decisions would represent federal elements because of their binding effect, while the Directives, which need to be "embedded" in the national system of member states in order to produce an effect, represent a confederal, international element. ${ }^{11}$

\subsection{EU MEMBER STATES}

Unlike international organizations, the EU can only have States as members, and there is no possibility for an international organization or other legal entity to become a member. In contrast, members of international organizations can be states, international organizations and other entities, which make the EU more similar to the federative system.

\subsection{COMPETENCES}

Having started as a community with purely economic goals, the EU is increasingly developing as a political union, gradually expanding its competence to issues that are part of the States' elements and belong to the area of States' sovereignty. The Lisbon Treaty stipulates that the EU acts in accordance with

\footnotetext{
10 Ćapeta, T., European Union courts - Courts of EU Member States as european courts, Zagreb, 2002, p. 10.

11 Bonechi, G.: The Legal Nature of the European Union: a Federal Approach, Luiss Guido Carli - Libera Universita internazionale, 2015, p. 29.
} 
the powers conferred on it by the Member States. ${ }^{12}$ However, the activism of the ECJ and the political guidelines of the European Council are to a great extent responsible for the expansion of EU competences on questions such as fundamental rights and defense.

The competences of the EU are wider than in international organizations since they are not exclusively technical and specific but rather more general. However, this is not a consistent criterion for legal differentiation between supranational organizations such as the EU and international organizations. ${ }^{13}$

\subsection{INSTITUTIONAL STRUCTURE IN THE EU}

The EU contains a mixture of intergovernmental and supranational institutional features which has made it peculiar from its beginnings. ${ }^{14}$ Initially, it was based on co-operation between the governments of the Member States, the decision-making center was the Council of Ministers as a representative of the national executive authorities, making the community similar to a typical international organization. In the 1960s, co-operation intensified, the European Parliament developed into an important decision-maker and the European Commission became an institution that would represent the executive power, though not in a typical manner.

The European Council carries out the function of the Head of State and contributes to the federalization of the European Union, as does the ECJ. ${ }^{15}$

All these institutions contributed to the emergence of a political union, whose mix of intergovernmental and supranational features some call a hybrid system. ${ }^{16}$

\subsection{THE QUESTION OF SOVEREIGNTY}

While EU Member States transfer part of their sovereignty to supranational bodies, in confederations and international organizations the states retain their sovereignty. In its judgment in Costa v. Enel, the ECJ held that "the Commu-

12 Consolidated version of the Treaty on the Functioning of the European Union, (OJ C 326, 26/10/2012) Art. 5.

13 Orakhelashvili, A.: The Idea of European International Law, The European Journal of International Law, vol. 17 (2) 2006, p. 343.

14 Magnette, P., Political system of the European Union, Biblioteka Politička misao, Pariz, 2009, p. 199.

15 Ibid., p. 231.

$16 \quad$ Ibid., p. 199. 
nity has rights deriving from the restriction of the sovereignty of the Member States." ${ }^{\prime 17}$ Member States thus lose the ability to exercise their rights that are usually associated with the concept of sovereignty. ${ }^{18}$

Paul Magnette regards the question not to be whether states lose or share sovereignty within the Union, but only how the sovereignty of the Member States is exercised in different ways within the network of institutions, norms and principles. ${ }^{19}$ Some believe that sovereignty, defined as one and indivisible, denies the federal solution and that the dual nature of the EU is thus obscured. ${ }^{20}$ Saurugger believes that the federalist approach to sovereignty needs to be abolished in order to create a new political system in which powers and sovereignty will be divided between different subjects and levels of governance. ${ }^{21}$

The Constitutional Courts of the Member States react differently to the issue of sovereignty within the EU. The Italian Constitution stipulates that "Italy agrees with the limitation of sovereignty necessary to ensure peace and justice between peoples." 22 The German Federal Constitutional Court states that "The Federal Republic of Germany participates in the European Union as an association of sovereign States to which sovereign powers are transferred. Authorization to exercise sovereign powers comes from the Member States. States permanently remain "custodians of the Treaties." 23 The ruling by the Polish Constitutional Court stated that "it is not enough to say that the European Union is considered as supranational organization - a category that the Polish Constitution has not foreseen. Member States remain sovereign entities - members of the Founding Treaties and the European Union. ${ }^{24}$ According to Branko Smerdel, the Republic of Croatia should find an example in the practice of the German Federal Constitutional Court and the constitutional courts of other States which have developed a theory of constitutional identity that stipulates that, contrary to the theory of full supremacy of all sources of European law

\footnotetext{
17 Case C-6/64 Costa v Enel [1964] ECR 585

18 Van Rossem, J. N., Between Autonomy and Dependence, The autonomy of EU Law: More is less?, The Netherlands, 2013, p. 26.

19 Magnette, P., Political system of the European Union, Biblioteka Politička misao, Pariz, 2009, p. 15.

20 Bonechi, G.: The Legal Nature of the European Union: a Federal Approach, Luiss Guido Carli - Libera Universita internazionale, 2015, p. 34

21 Saurugger, S., Theories and concepts of european integration, Biblioteka Politička misao, Paris, 2009, p. 87.

22 The Constitution of the Italian Republic, (Official Gazette no. 298), Art. 11.

23 Case 2 BVerfGE 2/08 [30/06/2009] Bundesverfassungsgericht.

${ }^{24}$ Case K 18/04 [11/05/2005] Polish Constitutional Tribunal
} 
over domestic law, including national constitutions, decisions must be made based on domestic constitutional law. ${ }^{25}$

The principle of subsidiarity is one of the mechanisms which allow the Member States to avoid the question of sovereignty and one of the fundamental elements the understanding of which allows us to see how and to what extent the federal (supra-national) government delegates more power to the lower level for the purpose of federal policy implementation. ${ }^{26}$ Countering the two basic levels of government is an essential feature of the federal system and one of the most visible dimensions of political life. ${ }^{27}$

An important factor in determining the legal nature and economic and political development of the EU is the ECJ. Its judgments change the nature of the organization and affect social, cultural and economic changes to the organization.

\subsection{ACTIVISM OF THE EUROPEAN COURT OF JUSTICE}

In the 1950s, the European Community was considered a largely international organization. Member States needed to determine the relationship between their own legislation and the community legislation, so they interpreted the provisions of their legislation in relation to the community legislation as well as the relation of domestic law to the international law. ${ }^{28}$ That is how the Community law was interpreted. Although concluded as international treaties, EC treaties have eventually taken on a constitutional character based on the rule of law. ${ }^{29}$

25 Smerdel, B.; Croatian constitutionality in the European Union - Appeal of the Eurorealist, Studia lexicographica, vol. 5 (1) 2011, p. 15.

26 Saurugger, S., Theories and concepts of european integration, Biblioteka Politička misao, Paris, 2009, p. 98.

27 Magnette, P., Political system of the European Union, Biblioteka Politička misao, Pariz, 2009, p. 20.

28 Ćapeta, T., European Union courts - Courts of EU Member States as european courts, Zagreb, 2002, pp. 3 - 4.

29 The ECJ found in the Les Verts case (Case C-294/83 Les Verts v European Parliament [1984] ECR 1339) that the European Community is based on the rule of law. The Community institutions and the Member States cannot avoid the question of whether the measures taken comply with the constitutional order of the Member States and the Founding Treaties. The ECJ interprets the Treaty and must be able to maintain the EU “institutional balance". D'Sa, Rose, M., The Legal and Constitutional Nature of the New International Treaties on economic and monetary union from the perspective of EU Law, European Current Law Issue, vol. 5, 2012, p. 23. 
The judgments of the ECJ Van Gend en Loos and Costa v. Enel have changed the perception of Community law from largely international to federal. The Van Gend en Loos judgment defines Community law as "a new order of international law in which the Member States have limited their sovereign rights, albeit in a restricted area, and whose subjects are not only the Member States but also their citizens." 30

The Community is defined as a new order of international law, which is more than a contract exclusively aimed at mutually agreed obligations between the contracting parties. ${ }^{31}$

In Costa v. Enel judgement, the ECJ has defined the community as a separate legal system, emphasizing its specific and original nature. The EC system must be autonomous because if national law were to take precedence over the Treaties, then the EC's own foundations would be questioned. "32 "The EEC Treaty has created its own legal system... Member States have restricted their sovereign rights, although in limited areas, and thus created a legal system which is obligatory for Member states as well as for their citizens." 33 By transferring jurisdiction and limiting the sovereignty of the Member States and by establishing direct effect and principles of supremacy, the Community has come closer to the federal order. The EU Court has taken a step towards the constitutionalization of the EC. ${ }^{34}$

As a reaction to change, the German Federal Constitutional Court described the EC in its 1967 judgment: "The community is neither a state nor a federal state. It is a Community of a specific nature in the process of closer integration into an intergovernmental organization in accordance with Article 24 of Grundgesetz by which the Federal Republic of Germany, in communion with other Member States, has transferred some sovereign rights." 35 The new body was established, autonomously and independently from the public authorities of all Member States. ${ }^{36}$

\footnotetext{
30 Case C-26/62 Van Gend en Loos [1963] ECR 1

31 Orakhelashvili, A.: The Idea of European International Law, The European Journal of International Law, vol. 17 (2) 2006, p. 343.

32 Van Rossem, J. N., Between Autonomy and Dependence, The autonomy of EU Law: More is less?, The Netherlands, 2013, p .18.

33 Case C-6/64 Costa v Enel [1964] ECR 585

34 Stone Sweet, A.: The Structure of Constitutional Pluralism, Yale Law School Faculty Scholarship, vol. 11 (2) 2013, p. 494.

35 Case BVerfGE 22 [18/10/1967] Bundesverfassungsgericht.

36 Czuczai, J., The autonomy of the EU legal order and the law-making activities of international organizations. Some examples regading the Council most recent practice, Brugge, 2012, p. 3.
} 
The importance of the supremacy of Community law over national law has also been confirmed in the Simmenthal case in which the ECJ emphasized that "provisions of national law which are contrary to Community law are non-applicable." ${ }^{37}$ In the Internationale Handelsgesselschaft the ECJ found that "the validity of EC law is assessed solely in the light of Community law and is within the jurisdiction of the ECJ." 38

Principles of supremacy are accepted by the courts and governments of Member states. The basis for the establishment of the principle of superiority of Community law was found by the ECJ in the autonomous and specific order of the Community, while national courts accepted the principle of supremacy as a constitutional consensus between the Member States. The Custodians of the Treaty are still Member States and the Community has an obligation to respect it. $^{39}$ The EU is defined as a sui generis system, a separate legal system with its own characteristics and specifics.

The abovementioned judgments were a big step towards EU federalization. The changes in the functioning of the EC happened because of the activist role of the ECJ, and not because the Member States had reached an agreement on this issue beforehand. However, these changes were later accepted by the Member States.

\section{EUROPEAN UNION AS A US FEDERATION?}

The development of the European Community went in the opposite direction from compared to the United States. The idea of a federal system has been present in the United States since its establishment, while in the European Union it was just one of many possibilities. ${ }^{40}$ Theoreticians of Europe have traditionally rejected the idea of a federal union like the one in the American constitutional tradition. ${ }^{41}$ The EU was created a long time after the emergence of states in Europe which had already developed their national identity, bu-

\footnotetext{
37 Case C-106/77 Amministrazione delle Finanze dello Stato v Simmenthal SpA [1978] ECR 629.

38 Case C-11/70 Internationale Handelsgesellschaft mbH [1970] ECR 1125.

39 Kwiecien, R.: The Primacy of European Union Law over National Law under the Constitutional Treaty, German Law Journal, vol. 6 (11) 2005, p. 1495.

40 Magnette, P., Political system of the European Union, Biblioteka Politička misao, Pariz, 2009 , p. 15

41 Bonechi, G.: The Legal Nature of the European Union: a Federal Approach, Luiss Guido Carli - Libera Universita internazionale, 2015, p. 24.
} 
reaucratic apparatus and a broad spectrum of public policies. ${ }^{42}$ In the United States, both levels of authority emerged at the same time, only one decade passed between the adoption of the Declaration of Independence of Former Colonies and the creation of the federal system, which makes the analysis of the balance between the EU and its Member States more difficult than that of the United States. ${ }^{43}$

The EU is not a State because it does not fulfill the conditions foreseen by international law. ${ }^{44}$ It was established based on contracts between sovereign states and not by sovereign citizens. ${ }^{45}$ The US Constitution was "made up of citizens", while the EC Treaties have been ratified by various national legislators. ${ }^{46}$ European constitutional architecture has never been confirmed by the European "demos". According to Alexis de Tocqueville, the main objective of the US Constitution was to divide the sovereignty into two parts: one should control the interests of the community, while the other should control the interests of the constituent States. ${ }^{47}$ Federalism implied dual government, dual sovereignty and dual citizenship. ${ }^{48}$

The Federation was easier to achieve in the US as there were no deep cultural, religious, and ethnic divisions in these areas. Alexis de Tocqueville thinks that four conditions were met for the success of US federalism. These are customs of local self-government, a common language, a political class dominated by lawyers and common moral convictions.

In the US, a large number of people of different nationalities accepted the language of the majority as the official language. Some see the lack of a common language as the most difficult barrier preventing the EU from becoming a federal community. If we consider the common language to be crucial for the

42 Magnette, P., Political system of the European Union, Biblioteka Politička misao, Pariz, 2009, p. 17.

43 Ibid.

44 Article 1 of the Montevideo Convention on the Rights and Obligations of the States provides: The State as a subject of international law should have the following characteristics permanent population, defined territory, government, the possibility of establishing relations with other states. Although the EU fulfills many of these conditions, it is clear that Member States have not ceased to exist as separate states. Wessel, Ramses A., Revisiting the International Legal Status of the EU, European Foreign Affairs Review, vol. 5, 2001, p. 523.

45 Bogdanor, V., European Studies at Oxford, Federalism and the nature of the European union, Oxford, 2003, p. 53.

46 B Bonechi, G.: The Legal Nature of the European Union: a Federal Approach, Luiss Guido Carli - Libera Universita internazionale, 2015, p. 25.

47 Bonechi, op. cit. p. 13.

48 Ibid. 
creation of a federation, it is almost impossible to create a federal European system in the EU. ${ }^{49}$

The US institutional structure does not differ essentially from that in the EU. The United States Constitution established the Congress as the legislative body, composed of a House of Representatives representing the "national" body and the Senate, representing an "international" body. ${ }^{50}$ In the EU, the European Parliament whose members are elected by citizens would be a "national" body, while the Council would represent an "international" body. The ECJ is the "Guardian of the Treaty", which is also the role of the US Supreme Court. The differences are obvious in the way of voting, appointment of judges and the possibility of giving separate opinions. ${ }^{51}$ The ECJ gradually started to decide on disputes of a political nature.

Differences between the US federal system and the EU system are in some part visible in the division of competences. While the US has classical sovereign competences in the area of foreign policy and defense, the EC primarily acted for the purpose of economic integration, first with the common market, and then with the common currency policy. However, that is changing since the EU is expanding its competences on issues such as defense and also through the creation of a common foreign policy, although this still not comprehensive as there is a diversity of opinions amongst the Member States regarding foreign affairs as well.

Cultural, political and economic conditions in the EU vary among different Member States. The EU and its Member States do not have a unique cultural identity, and Member States are afraid of losing theirs. In addition to cultural differences, there are also linguistic differences, social structures are quite different as well, and among some Member States there is a fear that a federally structured EU will lead to the disappearance of traditional states and cultures. EU Member States have all elements of nationality, different traditions and cultures, which distinguishes them from the US states.

The brief analysis shows that although there are similarities between two compared systems, EU is still not federalized in complete. Moreover, there is no chance that it will be federalized completely in the near future, since its political balance is very much questioned, which is not the case in the United States.

\footnotetext{
49 Podolnjak, R.,: The creation of the European Constitution as a "quasi-constitutional moment"', Zbornik Pravnog fakulteta u Zagrebu, vol. 55 (6) 2005, p. 1440.

50 B Bonechi, G.: The Legal Nature of the European Union: a Federal Approach, Luiss Guido Carli - Libera Universita internazionale, 2015, p. 27.

51 Magnette, P., Political system of the European Union, Biblioteka Politička misao, Pariz, 2009, p. 137.
} 


\section{THEORETICIANS ON THE LEGAL NATURE OF THE EU}

Most of the theoreticians who see the Union as an international organization will not deny that the EU has some federal characteristics. ${ }^{52}$ It is usually considered as an atypical model of an international organization based on international treaties, which remain international even when they are amended and changed. ${ }^{53}$ For them, the fact that it is a supranational organization does not exclude the possibility of it also being an international organization. ${ }^{54}$ Paul Magnette believes that the European Union is more integrated than a classical international organization in terms of scope of cooperation and imposed legal and political obligations, but it guarantees its members greater autonomy than those of federal states. ${ }^{55}$

Guggenheimm sees the EU as an autonomous system of rights that exist parallel to national and international legal systems. ${ }^{56}$

Jacques Dolores views the European Union as an unidentified political object. ${ }^{57}$

Branko Smerdel believes that it is a complex community that has its own historical precedents and comparative examples. ${ }^{58}$ Wessel considers the EU to be a community that represents a compromise between intergovernmental and supranationalist approaches. He uses the term "layered international organization". ${ }^{59}$ Wallace believes the EU is less than a federation, more than an inter-state regime. ${ }^{60}$

\footnotetext{
52 Van Rossem, J. N., Between Autonomy and Dependence, The autonomy of EU Law: More is less?, The Netherlands, 2013, p. 25.

53 Ibid.

54 Orakhelashvili, A.: The Idea of European International Law, The European Journal of International Law, vol. 17 (2) 2006, p. 343.

55 Magnette, P., Political system of the European Union, Biblioteka Politička misao, Pariz, 2009, p. 17.

56 Orakhelashvili, A.: The Idea of European International Law, The European Journal of International Law, vol. 17 (2) 2006, p. 343.

57 Ziller, J., The Nature of European Union Law, u Tratado de Derecho de la Union, Madrid, 2011, p. 60.

58 Smerdel, B.; Croatian constitutionality in the European Union - Appeal of the Eurorealist, Studia lexicographica, vol. 5 (1) 2011, p. 7.

59 Wessel, Ramses A., Revisiting the International Legal Status of the EU, European Foreign Affairs Review, vol. 5, 2001, p. 536.

60 Magnette, P., Political system of the European Union, Biblioteka Politička misao, Pariz, 2009, p. 192.
} 


\section{CONCLUSION}

The importance of determining the nature of the EU is manifested in a practical sense, as by providing definitions of phenomena and systems, we allow them to be more easily recognized and we are ready to see the advantages and disadvantages of each of them. If we do not know all characteristics of system, we can easily be drawn into the manipulations that the system can entail and which can be detrimental for democracy. The development of the European Union was characterized by periods of development and stagnation, and the question of the legal nature of the EU was one of the decisive factors that influenced the development of integration itself. From our brief analysis of the main political and legal determinants of the EC and the EU, we can conclude that the formal factors affect the change of the legal nature of the EU but these factors are also changing due to influential political factors. They represent the mixture of confederal and federal elements and form the content of the term sui generis, which is created on both legal and political levels. The changes on each level are reflected in the change of the content of the term sui generis.

The sui generis term represents a special organizational form with its own specific features. Since it contains characteristics that are specific and untypical, the concept of sui generis requires a thorough analysis to determine what it means. In the previous sections, the legal and political elements which were analyzed in comparison to federal, confederal and other elements, shows that the EU has the characteristics of each of these systems but not in their entirety. The sui generis concept serves as a term to define a mixture of all features, including those that are not characteristic of any of the foregoing systems.

Since some of the Member States advocate the federal organization of the EU, while some want to strengthen sovereignty and thus the confederal elements, the sui generis represents a successful compromise between the former and the latter. However, such an approach has its shortcomings since the term itself has no analytical value and historical significance. Sui generis does not mean the state, the super-state, nor the international organization, or any other form of international cooperation. It represents a unique system that cannot be compared in its entirety with existing systems. The term sui generis avoids the unambiguous answer to the question on which there is no consensus and an exact response to which could lead to political, economic and cultural consequences for the Member States.

We can conclude, there are no "United States of Europe" but there are many EU concepts. Some still see it as a confederal organization and want to limit the development of the EU as a federal community. The Confederal concept still has great support among Member States, and the reason is the preserva- 
tion of the sovereignty of Member States. On the other side, the federal concept of the European Union has been advancing for decades and, as has the role of the ECJ as a supranational court body. For some, it is an organization sui generis that avoids unequivocal qualifications of the EU such as a federal state or an alliance of states. With no final answer to this important question, it remains open for future analysis.

\section{LITERATURE:}

1. Baletić, M.: Legal Characteristics of the process of creation and enlargement of the European Union, Međunarodne studije: časopis za međunarodne odnose, vanjsku politiku i diplomaciju, vol. 6 (2) 2006.

2. Bogdanor, V., European Studies at Oxford, Federalism and the nature of the European union, Oxford, 2003.

3. B Bonechi, G.: The Legal Nature of the European Union: a Federal Approach, Luiss Guido Carli - Libera Universita internazionale, 2015.

4. Czuczai, J., The autonomy of the EU legal order and the law-making activities of international organizations. Some examples regading the Council most recent practice, Brugge, 2012.

5. Ćapeta, T., European Union courts - Courts of EU Member States as european courts, Zagreb, 2002.

6. Degan, Đ.: Confederalism, Politička misao, vol. 28 (2) 1991.

7. D'Sa, Rose, M., The Legal and Constitutional Nature of the New International Treaties on economic and monetary union from the perspective of EU Law, European Current Law Issue, vol. 5, 2012.

8. Kwiecien, R.: The Primacy of European Union Law over National Law under the Constitutional Treaty, German Law Journal, vol. 6 (11), 2005.

9. Magnette, P., Political system of the European Union, Biblioteka Politička misao, Pariz, 2009.

10. Mintas Hodak, Lj., European Union, Zagreb, 2010.

11. Orakhelashvili, A.: The Idea of European International Law, The European Journal of International Law, vol. 17 (2) 2006.

12. Podolnjak, R.,: The creation of the European Constitution as a "quasi-constitutional moment", Zbornik Pravnog fakulteta u Zagrebu, vol. 55 (6) 2005.

13. Posavec, Z.: A path towards a united Europe, Politička misao, vol. 28 (1) 1991.

14. Saurugger, S., Theories and concepts of european integration, Biblioteka Politička misao, Paris, 2009. 
15. Smerdel, B.; Croatian constitutionality in the European Union - Appeal of the Eurorealist, Studia lexicographica, vol. 5 (1) 2011.

16. Stone Sweet, A.: The Structure of Constitutional Pluralism, Yale Law School Faculty Scholarship, vol. 11 (2) 2013.

17. Van Rossem, J. N., Between Autonomy and Dependence, The autonomy of EU Law: More is less?, The Netherlands, 2013.

18. Wessel, Ramses A., Revisiting the International Legal Status of the EU, European Foreign Affairs Review, vol. 5, 2001.

19. Vukadinović, R. et al., European integration policy, Zagreb, 2005.

20. Ziller, J., The Nature of European Union Law, u Tratado de Derecho de la Union, Madrid, 2011.

21. Consolidated version of the Treaty on the Functioning of the European Union, (OJ C 326, 26/10/2012).

22. The Constitution of the Italian Republic, (Official Gazette no. 298).

23. The Montevideo Convention on the Rights and Duties of States (165 LNTS 19, 26/12/1933).

24. Case 89 BVerfGE 155 [12/10/1993] Bundesverfassungsgericht.

25. Case 2 BVerfGE 2/08 [30/06/2009] Bundesverfassungsgericht.

26. Case BVerfGE 22 [18/10/1967] Bundesverfassungsgericht.

27. Case K 18/04 [11/05/2005] Polish Constitutional Tribunal.

28. Case C-26/62 Van Gend en Loos [1963] ECR 1.

29. Case C-6/64 Costa v Enel [1964] ECR 585.

30. Case C-11/70 Internationale Handelsgesellschaft mbH [1970] ECR 1125.

31. Case C-106/77 Amministrazione delle Finanze dello Stato v Simmenthal SpA [1978] ECR 629.

32. Case C-294/83 Les Verts v European Parliament [1984] ECR 1339. 